\title{
Do work-life balance practices mediate in the relationship between female participation and financial performance?
}

\author{
María Dolores Odriozola and Elisa Baraibar-Diez \\ Department of Business Administration, University of Cantabria, \\ Santander, Spain
}

\begin{abstract}
Purpose - The purpose of this paper is to analyse the relationship between the participation of women in companies with financial performance. However, this relationship does not arise directly. The authors argue that the participation of women in the company's staff has a positive effect on the creation of work-life balance (WLB) practices, due to women have traditionally assumed family responsibilities, and subsequently these practices positively affect financial performance. WLB practices are a tool to balance employees' professional and personal goals.

Design/methodology/approach - This study aims to determine whether WLB practices mediate in the relationship between female participation in the workforce and financial performance on large companies listed in the Spanish Stock Exchange Index during the period from 2008 to 2013.

Findings - The main finding is that female participation in the workforce positively affects to the availability of WLB practices, but WLB practices are not a mediator to increase financial performance.

Originality/value - The study is a new contribution for academics and practitioners, since the WLB has a role of moderating variable; and the positive joint effect of female participation and WLB practices is tested over the company's outcomes, instead of over the individual employee behaviour like in previous literature. In addition, this effect is studied in a country with economic recession where corporate WLB practices have increased in the last decade.
\end{abstract}

Keywords Mediation, Financial performance, Female workforce, Work-life balance

Paper type Research paper

\section{Introduction}

According to the International Labor Organization report, although the share of women in the labour force, which reaches rates close to 50 per cent, is still lower than the share of men (approximately 76 per cent), this follows an increasing trend that is slowed down by the additional responsibilities that this segment assumes. The working days of women are still longer than those of men, because "women continue to take on most of the care tasks and unpaid housework, which limits their ability to increase their hours in paid and formal employment" (International Labor Organization, 2016). All the above give rise to situations in which family interferes with work (FIW), or when they assume more responsibilities in their work, also can be possible that work interferes with family (WIF) (Allen and Finkelstein, 2014).

A work-life conflict (WLC) situation causes negative outcomes in the employee, such as decrease in satisfaction at work (Bruck et al., 2002), increase of stress levels

\section{JEL Classification - M540}

(C) María Dolores Odriozola and Elisa Baraibar-Diez. Published in European Journal of Management and Business Economics. Published by Emerald Publishing Limited. This article is published under the Creative Commons Attribution (CC BY 4.0) licence. Anyone may reproduce, distribute, translate and create derivative works of this article (for both commercial and non-commercial purposes), subject to full attribution to the original publication and authors. The full terms of this licence may be seen at $\mathrm{http} / / /$ creativecommons.org/licences/by/4.0/legalcode

Work-life balance practices 
EJMBE

27,3

(Schieman et al., 2003), the possibilities of higher turnover (Balmforth and Gardner, 2006; Barrah et al., 2004, Wang et al., 2004), absenteeism (Grzywacz and Marks, 2000; Boyar et al., 2005; Lu et al., 2008), low productivity and lack of commitment (Lambert et al., 2006; Rothbard et al., 2005; Siegel et al., 2005). In order to resolve the WLC, managers could implement family-friendly practices into the strategy of the firm, known as practices of work-life balance (WLB), which emerged to balance work and personal demands and to avoid the loss of the high qualified employees.

WLB practices, defined as "those institutionalized structural and procedural arrangements as well as formal and informal practices that enable individuals to easily manage the conflicting worlds of work and family leaves" (Kar and Misra, 2013), help reduce FIW and WIF. In addition, academic literature cites benefits derived from the implementation of WLB practices such as increased satisfaction, retention of talent, or increased worker commitment among others. This work helps to understand whether the WLB practices (besides helping to improve the individual perceptions of the workers) can cause a positive effect on final outcomes of the companies, like the financial performance.

Increasing profitability through practices derived from human resources management is not a simple objective, since the manager must consider economic, social and cultural changes (Poelmans, 2005). These changes in the environment have implications for human resources management due to its impact on the personal and labour role of the employee. For example, when the environmental conditions become particularly difficult for companies, managers demand employees committed to the company and a high degree of dedication to work during the day (Hughes and Bozionelos, 2007; Hyman et al., 2003), creating conflict by pressures from work domains to family domains.

Most of the literature about WLB practices is focussed on Northern Europe or North America (Idrovo Carlier et al., 2012). However, research about WLB is not enlightening in other countries with different legal, cultural, economic and political conditions (Poelmans, 2005), such as countries of the south of Europe or Latin American countries. For example, Spain has been for other EU countries a model for job creation in the period of economic boom that preceded the outbreak of the financial crisis at the end of 2007, and the opposite during the economic crisis with job destruction (from an unemployment rate of 10.53 per cent in early 2005 to 22.56 per cent at the end of 2011).

Therefore, this paper aims to analyse whether female participation in the workforce affects positively to implement WLB practices in firms. Second, this study aims to contrast whether WLB practices act as a mediator of the relationship between female participation in the workforce and corporate financial performance, in a context where women frequently assume a traditional role, and the country's culture does not favour many family-friendly measures. The Spanish context, being part of the same cultural cluster as Portugal or Latin American countries, represents this case. We have composed a sample of large companies listed in the Spanish Stock Exchange (SSE), specifically in the Ibex-35 index, because they represent more than 95 per cent of the total capitalisation. The evolution of this index is the basic reference for the SSE nationally and internationally.

\section{Balance between personal and work life}

WLB practices are a subject of interest in the management of human resources, as their usefulness for companies has been debated by academics and practitioners. The research conducted about the effects of WLB practices can be classified according to two lines of research (see Figure 1) (Adame-Sánchez and Miquel-Romero, 2012). First, there are studies that analyse the consequences or impact of WLB practices on individual behaviours (such as attitudes of workers). This is the research line that gathers most of the studies of the academic literature about WLB. The changes that the use of WLB practices may 
produce in the employee (individually) can be physical or psychological. These changes in the employee may have positive consequences for the development of personal and professional life, and finally, they may be the cause of enhancement of employee performance (Adame-Sánchez and Miquel-Romero, 2012). Many studies developed in this line of research confirm that WLB practices increase staff loyalty and commitment, job satisfaction and productivity, as well as a reduction of absenteeism, sick days, tardiness, turnover intentions, or stress at work, among others (Lobel, 1999; Dex and Scheibl, 2000; Glass and Finley, 2002; Carrasquer and Martín, 2005; Hughes and Bozionelos, 2007; Albert et al., 2010). This literature on WLB focusses on the improvement of skills or behaviours of employees as a way to enhance organisational results than those obtained before the implementation of WLB practices.

The second line of research, considerably less studied than the first one, brings together the scarce evidence that analyse the relationship between WLB practices and organisational performance. Authors like Carrasquer and Martín (2005) support that WLB practices are a source of competitive advantages for the company, and more specifically, the study of Konrad and Mangel (2000) demonstrates how WLB practices are predictors of the company's performance. However, due to the shortage of papers in this line, the impact of WLB practices on organisational performance remains unclear in the current literature (Meyer et al., 2001; Ngo et al., 2009), and the inconclusive findings about the impact of these practices in the firm's profitability highlights the need to develop new contributions (Bardoel et al., 2008). In Spain, a growing number of companies have implemented WLB practices in response to demands of employees in the last decade (Albert et al., 2010), but the study on the potential impact of such practices on firm performance is in a nascent stage, becoming into an object of attention and debate (Mañas and Garrido, 2008). The difficulties of the employee to balance the time dedicated to working and personal lives are influenced by demographic, cultural and economic changes in their environment.

The main socio-demographic change that has caused the greatest impact on the labour market has been the incorporation of women into it. Women have traditionally assumed family responsibilities, without sharing them with men. Some authors claim that the labour role is added to other roles that women traditionally was performing, and this has hampered their opportunities to reconcile work and family in a more difficult way than men do it (Forma, 2009). Besides, there are other socio-demographic changes in families, such as the division of family and domestic responsibilities between couples, couples with children where both parents develop a labour career, the increase of single parenting, fathers heavily involved in parenting, the employees seeking a better quality of life and the necessity to take care of elderly people (De Luis-Carnicer et al., 2004; Cánovas et al., 2005; Hughes and Bozionelos, 2007). However, women are still with the highest burden of family and domestic responsibilities.

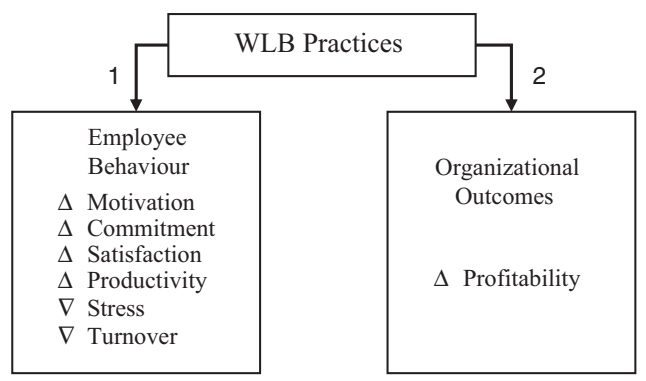

Figure 1. Two lines of research about the effects of WLB practices 
EJMBE 27,3

252

Furthermore, cultural aspects have had a prominent role in the development of WLB practices in different regions. In this regard, Spain has extra difficulties to balance work and family time due to its long school holidays, long working days (typically from nine till eight with a long lunch break) and limited existence of part-time work arrangements (Macinnes, 2005). According to data from the European Commission, Spain has more than $18 \mathrm{~m}$ employees, and only $2.5 \mathrm{~m}$ have a part-time job (average data for the period 2008-2013), of which 76.53 per cent are women. If we analyse the part-time jobs of workers who have children, 93.12 per cent are women and 6.92 per cent men (see Table I).

Moreover, Spanish firms have taken a long time to support family-friendly culture, possibly as a consequence of customs and established traditions (Cegarra-Leiva et al., 2012a), and indeed, Spain has the lowest financial aid to families with children in the European Union (De Luis-Carnicer et al., 2004; Cegarra-Leiva et al., 2012b). The northern European countries, among which stands Norway, are considered to give more importance to the support of WLB practices (Seierstad and Kirton, 2015). Compared with other European countries, the Spanish culture stands as one in which the family is considered a strong institution but also where the participation of women in the labour market continues to rise (De Luis-Carnicer et al., 2004). In Spain, the visibility of the role of women and the growth of female participation rates in the company have been supported by gender policies. The Organic Law for effective equality of women and men came into force in 2007. It becomes clear that this cultural context is quite different from those represented in previous research about WLC and WLB (De Luis-Carnicer et al., 2004). The academic literature review developed by Poelmans (2001) on the field of WLB noted the absence of empirical studies conducted for Spanish companies.

Finally, economic changes can be an important factor to determine if firms develop WLB practices or if the economic situation allows employees to use them. According to Hyman et al. (2003) and Grau-Grau (2013), the economic crisis and the perceived insecurity in the labour market increase the continual presence of employees at the workplace as a way to demonstrate their commitment. From 2008 to the present time, the countries of southern Europe have been suffering high unemployment rate. Besides, the labour law in Spain was changed to allow a more flexible policy of recruitment and redundancy, which has resulted in an increase of temporary jobs and the reduction of permanent work contracts (Valle et al., 2001). This situation has created insecurity in the labour market and less demanding employees. The economic crisis in Spain has exacerbated the complexity of balancing work and personal life, because it had a negative impact on the control and autonomy that Spaniards had of their jobs; diminishing the level of flexibility at work, and increasing the level of stress (Grau-Grau, 2013).

Table I.

Employed persons working part-time in Spain

\begin{tabular}{lcccrcr}
\hline & \multicolumn{3}{c}{ Total household composition } & \multicolumn{3}{c}{ Single adult with children } \\
Year & Total & Males (\%) & Females (\%) & Total & Males (\%) & Females (\%) \\
\hline 2008 & $2,428.9$ & 20.85 & 79.15 & 35.2 & 11.93 & 88.35 \\
2009 & $2,526.4$ & 21.32 & 78.67 & 43.0 & 5.12 & 94.88 \\
2010 & $2,460.1$ & 21.74 & 78.26 & 64.5 & 7.91 & 92.09 \\
2011 & $2,612.0$ & 24.36 & 75.64 & 57.2 & 4.37 & 95.63 \\
2012 & $2,626.0$ & 25.30 & 74.70 & 74.8 & 8.42 & 91.58 \\
2013 & $2,793.1$ & 27.23 & 72.77 & 100.3 & 3.79 & 96.21 \\
Average & $2,574.4$ & 23.47 & 76.53 & 62.5 & 6.92 & 93.12 \\
Evolution rate & & 30.57 & -8.05 & & -68.25 & 8.90
\end{tabular}

Note: Employed population between 15 and 64 years (in thousands)

Source: Eurostat - Number of persons by sex, age groups, household composition and working status 


\section{Can WLB practices be a mediator between women in the workforce and organisational outcomes?}

The female participation in the workforce has been considered in academic literature as an important aspect to research about. Academic literature mentions competitive advantages derived from the female participation in the workforce, that in this work have been classified in three epigraphs. First, advantages derived from individual job performance based on a female style. Second, advantages derived from the creation of work teams with greater gender diversity. Finally, advantages derived from what the participation of women in the company represents for other employees and external stakeholders:

(1) In the performance of their work, women are characterised by being more likely to consider social causes within the company (charitable donations) (Williams, 2003), have a more interactive and inclusive style than men (Berry and Franks, 2010), encourage participation by sharing information and facilitating direct communication channels with their subordinates (Dezsö and Ross, 2012), and they are considered less hierarchical and more cooperative than men (Eckel et al., 2008).

(2) Work teams with gender diversity also have advantages, such as enrichment of work leading to greater diversity and quality of decisions (Rogelberg and Rumery, 1996), new points of view about strategic issues (especially those relating to female consumers, employees and business partners (Daily et al., 1999 in Dezsö and Ross, 2012)), and greater creativity and innovation.

(3) A higher rate of female participation in the workforce motivates other women to commit to the company and promote in it. For the external stakeholders, the female participation in the company is a sign that the company is committed to the diversity of its workforce, it gives a more inclusive and respectful culture, and improves its image and reputation (Dezsö and Ross, 2012).

Theoretically, the participation of women in the business world has several positive connotations that could help to obtain higher financial results (Miller and Triana, 2009). However, there is no unanimity in the results found. Authors considering that female participation can have a positive effect on $\mathrm{FP}$, but argue that it is derived from other mediating variables (Dezsö and Ross, 2012). In this sense, WLB could be a mediating variable of this relationship, since WLB practices are increasingly spreading to encourage and facilitate the participation of women in the workplace, and those companies with a higher percentage of women are more likely to put WLB practices at their disposal. Straub (2007) confirms in her study 'European companies' efforts to enhance a gender-equitable workplace by implementing work-life balance programmes" that WLB practices enhance the advance of women's careers.

Glass and Estes (1997) classified common WLB practices into three categories: family and parental leave, flexible work arrangements and child and dependent care. Managers have to choose which practices are most suitable for the company and for their employees. It is important to consider that WLB practices have a cost in the short term. Some WLB practices involve an organisational cost (selecting a new employee to replace a person who has an extended leave or to manage potential conflicts between workers arising from the redistribution of work shifts to favour staff that need balance work and family time), and it is also possible a monetary cost (paid leaves, financial aids for children of employees, etc. (Matus et al., 2007; Albert et al., 2010).

Otherwise, WLB practices reduce costs in human resource management of absenteeism (Osterman, 1995), tardiness, turnover, recruitment (recruiting high-quality professionals or retaining their employees) (Bruck et al., 2002; Lambert, 2000), or minor accidents and grievances (Havlovic, 1991; Hall and Parker, 1993; Greenhaus and Parasuraman, 1997;

Work-life balance practices 
EJMBE

27,3

254

Lobel, 1999; Konrad and Mangel, 2000). Family-friendly benefits can also provide a competitive advantage to businesses, for example, flexitime arrangements with employees can help organisations to maintain flexible structures to respond to changing conditions (Kossek and Ozeki, 1998).

Finally, workforce characteristics and employee demands are fundamental for the company in the decision to implement WLB practices. Pasamar and Valle (2011) highlight the following reasons to decide facilitate WLB practices: coercive pressures (pressures exerted by other organisations or by the state through the enactment of laws), mimetic pressures (giving rise to the imitation when these measures prevail in a given sector or by the perceived success of companies that have adopted them), and normative pressures (because society demands an active role of the organisations on this issue as part of their moral obligations). Therefore, whether WLB practices are enhancers of the possible positive impact that female participation in the workforce can have on the firm profitability will be a key reason to implement them by the manager (Pasamar and Valle, 2011; Cegarra-Leiva et al., 2012b).

The importance of demonstrating that these social practices fulfil a social and economic purpose at the same time would be a trigger for their propagation. Due to cultural characteristics that define the labour market in Spain, the implementation of WLB practices can be a differentiating feature for companies that offer them to their employees. Therefore, two different hypotheses are suggested to be tested in this paper:

H1. Female participation in the workforce has a positive influence to make available WLB practices on the firm.

H2. WLB practices mediate the relationship between female participation in the workforce and firm financial performance.

To test whether the firm performance could be explained through WLB practices and female participation in workforce, we considered the main control variables that have been justified in previous studies. The following variables were measured using public available information to increase the chances to compare this study in future periods.

\section{Size}

The literature review confirms that size can have a positive impact on performance, so it is considered as a control variable. The resource theory advocates that large firms have more resources than small firms to implement singular strategies that allow them to obtain competitive advantages (Barney, 1991). Also a greater size can benefit the company through economies of scale (Osterman, 1995) or they can have a greater market share.

\section{Strategy of differentiation}

Companies adopt a differentiation strategy to make their products stand out against the competitors, in order to retain customers and achieve a supplement on the price of their products. Previous studies concluded that the higher financial effort to differentiate its products or services, the greater the benefit obtained from their activities, exerting a positive effect on the financial results (Fernández and Luna, 2007; Miller and Triana, 2009).

\section{Debt}

The debt variable is necessary in this analysis because it indicates available financial resources in the company. The higher the debt, the higher the risk assumed by the company and less capacity to invest in socially responsible practices (Roberts, 1992). 
The sectorial differentiation among the companies of the sample is a factor that must be considered for empirical testing, since the sector of business activity establishes intersectional features, such as the competitiveness of each sector, the degree of monopoly, and differences in demand or asset specificity among others. According to the academic literature, the sector of activity influences the profitability of firms (Calvo and Martínez, 2004). There are also sectorial differences in the level of awareness with WLB policies. According to the findings of Albert et al. (2010), Spanish companies belonging to financial sectors and consumer goods (food, pharmaceutical and cosmetic) are more likely to develop such practices.

\section{Methodology}

The proposed model examines the mediator effect of WLB practices on the relationship between female participation and the profitability of the firms listed in the Spanish Ibex-35 index during the financial crisis period. Mediation models have one independent variable, one mediator and one final outcome variable. In this case, the effect of female participation $(X)$ on financial performance $(Y)$ can be divided into two effects: the indirect effect $a b$, which is the product of the direct effects $a$ and $b$, and the direct effect $c$ (see Figure 2).

To test $H 1$ and $H 2$ we follow the methodology to analyse the mediator effect proposed by Baron and Kenny (1986) and Miller and Triana (2009) with four sequential steps through multiple linear regressions estimated by ordinary least square with the software SPSS. Below, the four steps for our model are detailed:

- Step 1: female participation on workforce has to be correlated with FP;

- Step 2: female participation on workforce should be significant to explain WLB;

- Step 3: WLB must influence FP while controlling female participation on workforce; and

- Step 4: previous relationship between Female participation on workforce and FP must be reduced in presence of WLB practices.

\section{Sample}

In order to test the proposed model, firms listed in the Ibex-35 between 2008 and 2013 have been selected. The selection of these firms is justified because they are the companies with the greatest capitalisation (more than 95 per cent of the total capitalisation) of the SSE, and the evolution of the index is the reference of Spanish stock market. To support this argument, academic literature confirms that large firms (like the firms listed in Ibex-35) are "more likely to have engaged in CSR activities" (Husted and Allen, 2007) in a formal or an informal way (Melé et al., 2006); because they have to respond to the demands of a large number of stakeholders (Martínez et al., 2016), and they have more resources than small firms (Barney, 1991; Osterman, 1995). Besides, the fact that all these firms are exposed to

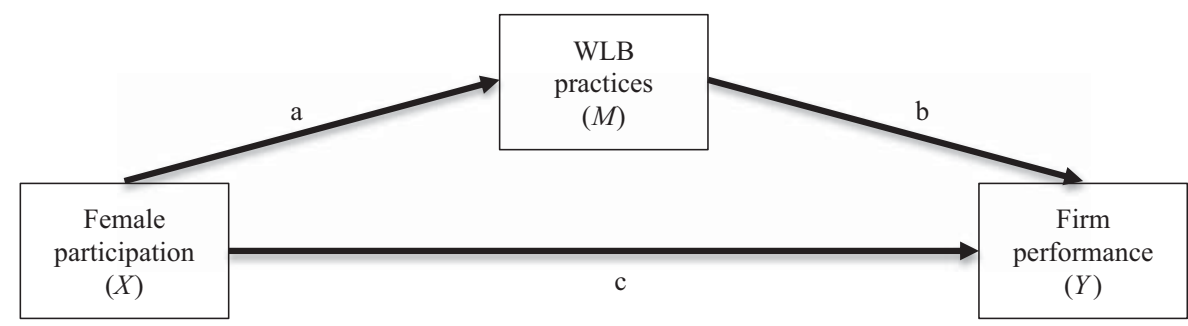

Figure 2. Pathway of a mediation process of the relationship between Female participation in workforce and firm performance 
EJMBE 27,3

\section{6}

\section{Data collection}

In order to increase the usefulness of this study for the decision making process by human resources managers with respect to WLB practices, a measure of profitability based on accounting has been used. Return on assets is used as a proxy variable of profitability (Fernández and Luna, 2007). This measure is widely used in the management field, and therefore easily accessible. WLB practices variable is measured by the WLB index developed by the observatory for corporate social responsibility of the trade union UGT (General Union of workers) in collaboration with the Research Group on Corporate Social Responsibility at the University of Valencia. The information of this Observatory has been previously used in several studies (Gil-Estallo et al, 2009; Prósper and Reche, 2011; Coller et al., 2014; Odriozola and Baraibar-Diez, 2017). This index is published in the report called "Cultures, Policies and Practices of Corporate Social Responsibility (CSR) of Ibex-35 companies" disclosed on the web page of the Observatory (see Observatory for Corporate Social Responsibility - UGT). The WLB index is based on the normative standards of social assessment processes which express the aspirations for quality and progress of the European social model (European Commission, 2001). Furthermore, considering the most

Oil and energy

Raw materials, industry and construction

Consumer goods and services

Financial and property
Electricity and gas

Oil

Engineering Mineral, metals and transformation

Electronics /Software Capital goods Textile /Apparel/Footwear Highways /Parking Media and advertising Technology and telecommunications Investment services
Table II.

Ibex-35 companies analysed
Enagas SA

Endesa SA

Gas Natural SDG SA

Iberdrola SA

Red Eléctrica Corporación SA

Repsol SA

Abengoa SA

Acerinox

Acciona SA

ACS SA

Ferrovial SA

Fomento de construcciones y

contratas SA

Obrascon Huarte Lain SA

Sacyr Vallehermoso SA

Indra sistemas SA

Gamesa Corporación Tecnológica SA

Industria de diseño textil SA

Abertis infraestructuras SA

Mediaset España comunicación S.A.

Amadeus

Telefónica SA

Banco Popular

Banco Sabadell

Banesto

Bankinter

BBVA

Caixabank

Mapfre

Santander 
applied practices for Spanish firms, either by cost or by its utility, according to the study of Albert et al. (2010) and Cegarra-Leiva et al. (2012b), this index measures the performance of the following actions: short working day, part-time work, flexible working hours and maternity leave in excess of the legal minimum. The information published in CSR reports (considering CSR: "the firm's consideration of, and response to, issues beyond the narrow economic, technical and legal requirements of the firm in order to achieve social benefits, along with the traditional economic profits that the company seeks" (Davis, 1973)) is subjected to an evaluation process to verify whether the company implements the measures included in the index. If an analysed company informs about the availability of four measures it obtains the maximum score (33 points), three measures is a satisfactory level (25 points), two measures is a sufficient level of development (14 points) and one measure is insufficient (7 points). In addition, in the same report where the WLB practices index is collected, we can obtain the percentage of women over the total number of firm's employees for the IBEX 35 companies, which serve to measure the female participation on the workforce.

The measures used for the control variables included in the model are described below. Total assets was used as a measure of size (Griffin and Mahon, 1997; Brammer and Millington, 2006; Mahoney and Roberts, 2007). The variable strategy of differentiation was measured using a proxy, the ratio of advertising and $R \& D$ expenses divided by the net sales of the company. Explicit data for the advertising and R\&D expenses of each company or sector could not be obtained, so following the measure taken by Fernández and Luna (2007) we estimate these costs from the other operating costs entry in the company accounts, which covers these expenses. The ratio used to measure the level of debt of a company, and therefore the risk, is the total long-term debt divided by total assets (Mahoney and Roberts, 2007). Sector activity was represented by dummy variables. Sector 1 takes value 1 if the company belongs to the sector Oil and Energy, otherwise 0 . Sector 2 takes value 1 if the company belongs to the sector Raw materials, industry and construction, otherwise 0 . Sector 3 takes value 1 if the company belongs to the sector Consumer goods and services, otherwise 0 . The Financial and Property sector is the omitted category in the regressions because of the dummy variable trap. The sector variable follows the sector classification defined by the Madrid Stock Exchange. The dependent variable, size, debt and the data used to obtain the differentiation strategy were obtained from the accounts of each firm using the SABI database.

\section{Results}

These results were computed using the statistical software IBM SPSS Statistics Version19. Table III shows how female participation on workforce has a positive

\begin{tabular}{|c|c|c|c|c|c|c|c|c|}
\hline Variables & Mean & $\mathrm{SD}$ & 1 & 2 & 3 & 4 & 5 & 6 \\
\hline${ }^{\mathrm{a}} \mathrm{FP}(\%)$ & 8.64 & 47.05 & 1 & & & & & \\
\hline${ }^{b} W L B$ & 28.35 & 6.56 & 0.022 & 1 & & & & \\
\hline${ }^{\mathrm{c}}$ Size (thousands $€$ ) & $8.34 \mathrm{e}+07$ & 2.35 & 0.008 & -0.056 & 1 & & & \\
\hline${ }^{\mathrm{d}} \operatorname{Debt}(\%)$ & 44.30 & 30.34 & $-0.164^{* *}$ & -0.067 & $-0.419 * * *$ & 1 & & \\
\hline 'Strategy of Differe. & $0.961 \mathrm{e}+6$ & $2,36 \mathrm{e}+6$ & -0.012 & -0.075 & $0.909 * * *$ & $-0.311^{* * * *}$ & 1 & \\
\hline${ }^{\mathrm{f}}$ Female participation $(\%)$ & 35.55 & 15.09 & $0.163^{* *}$ & $0.241^{* * *}$ & $0.318^{* * *}$ & $-0.405^{* * *}$ & $0.357 * * *$ & 1 \\
\hline
\end{tabular}

Notes: The above variables are measured as follows: ${ }^{a}$ Return on assets (\%). ${ }^{b}$ WLB Index (0-100). ${ }^{\text {CTotal }}$ Assets (thousands of euros). ${ }^{\mathrm{d}}$ Ratio: total long-term debt/total assets. ${ }^{\text {eRatio: }} \mathrm{R} \& \mathrm{D}$ and advertising expenses/

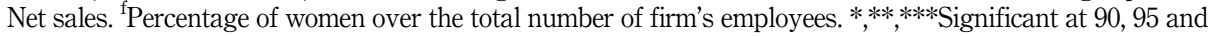
99 per cent levels, respectively

Table III.

Means, SD and Pearson correlations coefficients 
EJMBE 27,3

258

correlation with corporate financial performance, and Table IV shows that female participation is significant at the level of 95 per cent in the regression to explain the financial performance (as dependent variable). Then, the expected relationship between these variables according to the academic literature is corroborated, and it complies with Step 1 of the Sequential analysis.

The regressions developed to test the following steps are showed in Tables V and VI. Female participation is significant at level of 95 per cent to explain WLB practices, fulfilling the requirement of step 2 in the sequential steps for the mediating model. In addition, the $H 1$ ("Female participation in the workforce has a positive influence to make available WLB practices on the firm") of this study is confirmed.

Finally, the results obtained in the regressions for models 3 and 4 (see Table VI), show that WLB practices has not a significant effect on financial performance. So, the second hypothesis (H2) is rejected. In addition, the steps 3 and 4 were not fulfilled in the statistic sequential analysis.

\begin{tabular}{|c|c|c|}
\hline \multicolumn{3}{|c|}{ Linear Regression - Data estimation } \\
\hline Dependent variable: financial performance & $\beta$ standardized & $p$-value \\
\hline \multicolumn{3}{|l|}{ Control variables } \\
\hline Size & 0.195 & 0.322 \\
\hline Strategy & -0.370 & $0.050 * *$ \\
\hline Debt & -0.378 & $0.002^{* * * *}$ \\
\hline Sector 1 & 0.599 & $0.000^{* * * *}$ \\
\hline Sector 2 & 0.443 & $0.005^{* * * *}$ \\
\hline Sector 3 & 0.460 & $0.000 * * *$ \\
\hline \multicolumn{3}{|l|}{ Independent variable } \\
\hline \multirow[t]{2}{*}{ Female participation } & 0.300 & $0.012^{* *}$ \\
\hline & $R^{2}$ a & \\
\hline
\end{tabular}

Table IV.

Results of regression: female participation in workforce on financial performance

Notes: ***,***Significant at 90, 95 and 99 per cent levels, respectively 


\begin{tabular}{|c|c|c|c|c|c|}
\hline \multirow[b]{2}{*}{ Dependent variable: financial performance } & $\begin{array}{r}\text { gression - Data e } \\
\text { Mode }\end{array}$ & mation & \multicolumn{2}{|c|}{ Model 4} & balance \\
\hline & $\beta$ standardized & $p$-value & $\beta$ standardized & $p$-value & practices \\
\hline \multicolumn{6}{|l|}{ Control variables } \\
\hline Size & 0.211 & 0.298 & 0.184 & 0.354 & \multirow{6}{*}{259} \\
\hline Strategy & -0.359 & $0.062 *$ & -0.367 & $0.052^{*}$ & \\
\hline Debt & -0.415 & $0.001^{* *}$ & -0.374 & $0.002^{* *}$ & \\
\hline Sector 1 & 0.427 & $0.000 * * *$ & 0.608 & $0.000 * * *$ & \\
\hline Sector 2 & 0.290 & $0.051 * *$ & 0.441 & $0.005^{* *}$ & \\
\hline Sector 3 & 0.510 & $0.000 * * *$ & 0.452 & $0.000^{* * * *}$ & \\
\hline \multicolumn{6}{|l|}{ Mediator } \\
\hline Work-life balance & 0.028 & 0.723 & -0.043 & 0.600 & \\
\hline \multirow{2}{*}{\multicolumn{5}{|c|}{$\begin{array}{l}\text { Independent variable } \\
\text { Female participation }\end{array}$}} & \multirow{4}{*}{$\begin{array}{r}\text { Table VI. } \\
\text { Results of regression: } \\
\text { WLB as mediator of } \\
\text { female participation in } \\
\text { workforce and firm } \\
\text { performance } \\
\text { relationship }\end{array}$} \\
\hline & & & 0.322 & $0.011^{* *}$ & \\
\hline I the 1 & $\begin{array}{r}R=0 \\
R^{2} \text { adjusted } \\
F=5.654 \text { si }\end{array}$ & $\begin{array}{l}8 \\
=0.180 \\
=0.000\end{array}$ & $\begin{array}{r}R=0 . \\
R^{2} \text { adjusted } \\
F=5.983 \text { si }\end{array}$ & $\begin{array}{c}0.220 \\
=0.000\end{array}$ & \\
\hline \multicolumn{5}{|c|}{ Notes: $* * * * * *$ Significant at 90,95 and 99 per cent levels, respectively } & \\
\hline
\end{tabular}

Table VII summarises the relationships found between the main variables considered to test the mediating effect through a sequential step model from the results found in the various linear regressions. Steps 1 and 2 verified what was expected in $H 1$. The female participation in the company contributes to increase the entrepreneurial business value, and also explains that the company make available more WLB practices. However, steps 3 and 4 are not fulfilled, since WLB practices are not significant to explain greater financial performance.

\section{Discussion, conclusion and implications}

This research focusses on clarifying whether WLB practices mediates in the relationship between female participation on workforce and financial performance. According to the results obtained, the mediating effect is not confirmed because the relationship between WLB practices and profitability cannot be significant for the period studied. Meyer et al. (2001) analyse the impact of different WLB practices on the profitability of the company, and they concluded that not all practices have a significant positive effect on corporate profitability.

Motivational theories support that only when employees have their basic needs covered they will be concerned about the highest needs. So, the lack of job security perceived by the employee during the period studied in the Spanish market could explain the absence of significant correlations between WLB practices and profitability in a period of economic recession. In an environment of economic instability, where the risk of unemployment is higher, employees may feel more concerned about meeting their basic needs, rather than

\begin{tabular}{|c|c|c|c|c|c|}
\hline & & & Estimate & $Z$ & \\
\hline$\checkmark$ Step 1: & $X \rightarrow Y:=c$ & Female participation $\rightarrow$ Financial performance & 0.300 & $0.012^{* *}$ & \\
\hline$\checkmark$ Step 2: & $X \rightarrow M:=a$ & Female participation $\rightarrow$ WLB practices & 0.519 & $0.000^{* * * *}$ & \\
\hline$x$ Step 3: & $M \rightarrow Y:=b$ & WLB practices $\rightarrow$ Financial performance & 0.028 & 0.723 & \\
\hline$x$ Step 4: & $X \rightarrow M \rightarrow Y:=\mathrm{ab}$ & WLB practices $\rightarrow$ Financial performance & -0.043 & 0.600 & Summary of the \\
\hline & & Female participation $\rightarrow$ Financial performance & 0.322 & $0.011^{* *}$ & $\begin{array}{l}\text { Summary of the } \\
\text { mediating model in }\end{array}$ \\
\hline \multicolumn{5}{|c|}{ Notes: *******Significant at 90, 95 and 99 per cent levels, respectively } & sequential steps \\
\hline
\end{tabular}


EJMBE

27,3

260

voluntary practices in WLB. The European Foundation for the Improvement of Living and Working Conditions (2010) affirms that the economic downturn is likely to lead to increased job insecurity and work intensification, being contrary to the will of the companies that support current family responsibilities to improve the quality of jobs (Kossek et al., 2010).

Another possible explanation for this result may be that WLB practices were more valued by workers at the first years of their implementation. They were innovative practices and sign of differentiation among firms, and over time, those practices are more common and they have less impact on employees' behaviour. In the sample in this study, the average value given to the WLB practices index is 28.35 , and there are no significant differences among sectors. This aspect can be justified by the Institutional Theory (Acosta et al., 2007; Martínez et al., 2016), according to which companies adopt forms of behaviour or policies to respond to the demands of their stakeholders because their competitors are also carrying them out, and consider it a way to legitimise their activity socially. All this leads them to reach a similar level or status. Taking the above into account, making available more WLB practices than the competitors could be still a way to differentiate. This explanation is supported by Huselid (2003), who confirms the positive impact of high performance work practices in corporate profitability, but states that the positive impact loses effect gradually in the long term. This argument is based on traditional economic theory, because the returns on investment in a differentiating asset, such as WLB practices in the context of the Spanish business, tends toward equilibrium as more and more companies invest into it. Instead, the participation of women in the workforce shows greater divergence. The average percentage of women in IBEX 35 companies is 35.5, although there are sectors that show greater gender inequality than others. Sectors 1 and 2 have an average of 24.51 and 26.40, respectively; while sectors 3 and 4 reach 49.74 and 48.05 , respectively. The participation of women is higher in service sectors with customer service tasks, as opposed to more traditional sectors (energy and construction).

The results of the present study have practical and academic implications. The participation of women in the workforce is a powerful tool, due to the competitive advantages derived from the gender diversity in the firm, but WLB practices in similar stage to competition could not cause a substantial variation in profitability in the short term. Furthermore, the results of this study could serve as a reference for countries with a similar culture. Historically between the Iberian countries (Spain, Portugal and the nations of Latin America) there have been strong cultural ties, highlighting issues such as the political and cultural legacy, language, religion or lifestyle (Idrovo Carlier et al., 2012). Comparative studies about the culture and support of WLB practices in the workplace for Spanish and Latin American companies (Idrovo Carlier et al., 2012) stand out that in Latin America, the number of companies supporting WLB is slightly higher than for Spain, with the singularity that Latin Americans are more sensitive with family responsibilities (with practices such as holiday calendars or permits) but the implementation of WLB practices is less formal.

Other authors such as Maxfield (2005) notes that in Latin American culture, because of the high roots of family responsibilities, women find obstacles to promote or be part of the senior management of the company (while globally 40 per cent of the management positions are held by women in the case of Latin America up 25 per cent, and only an average of 15 per cent is part of the senior management of companies), and as in Spain, WLB practices are at a nascent stage.

This work also has limitations. WLB index is based on the evaluation of the disclosure of information that companies publish in their corporate social responsibility reports about WLB practices, so we do not know if these practices are being used or not by employees. Nevertheless, many studies argue that the mere availability of WLB practices, even if the employees do not make use of them, have a positive effect on the results of the organisation (Scandura and Lankau, 1997; Cegarra-Leiva et al., 2012b). Future studies could analyse 
the impact on financial performance of indicators that demonstrate the use of WLB practices (number of extended leaves, duration of maternity and maternity leave, jobs developed through teleworking, etc.). Finally, considering the nascent stage of this line of research, there are many possibilities and new opportunities for future contributions. In this sense, it would be interesting to differentiate the role of female participation by category, department or power in the firm, to know whether there are differences in the implementation of WLB practices depending on those variables. In addition, a sample collected during more years could analyse whether WLB practices need a long-term period to impact on organizational outcomes.

\section{References}

Acosta, R.M.V., Dominguez, M.J.M. and Ligero, F.R. (2007), "Análisis de la responsabilidad social corporativa desde tres enfoques: stakeholders, capital intelectual y teoría institucional", Conocimiento, innovación y emprendedores: camino al futuro, Huelva, pp. 3130-3143.

Adame-Sánchez, C. and Miquel-Romero, M.J. (2012), “Are Spanish SMEs good places to work?”, Management Decision, Vol. 50 No. 4, pp. 668-687.

Albert, R., Escot, L., Fernández, J.A. and Palomo, M.T. (2010), "Las políticas de conciliación de la vida familiar y laboral desde la perspectiva del empleador. Problemas y ventajas para la empresa", Cuadernos de Trabajo, Escuela Universitaria de Estadistica Universidad Complutense, Vol. 2 No. 1, pp. 1-29.

Allen, T.D. and Finkelstein, L.M. (2014), "Work-family conflict among members of full-time dual-earner couples: an examination of family life stage, gender, and age", Journal of Occupational Health Psychology, Vol. 19 No. 3, pp. 376-384.

Balmforth, K. and Gardner, D. (2006), "Conflict and facilitation between work and family: realizing the outcomes for organizations”, New Zealand Journal of Psychology, Vol. 35 No. 2, pp. 69-76.

Bardoel, E.A., De Cieri, H. and Mayson, S. (2008), "Bridging the research-practice gap: developing a measurement framework for work-life initiatives", Journal of Management and Organization, Vol. 14 No. 3, pp. 239-248.

Barney, J. (1991), "Firm resources and sustained competitive advantage", Journal of Management, Vol. 17 No. 1, pp. 99-120.

Baron, R.M. and Kenny, D.A. (1986), "The moderator-mediator variable distinction in social psychological research: conceptual, strategic, and statistical considerations", Journal of Personality and Social Psychology, Vol. 51 No. 6, pp. 1173-1182.

Barrah, J.L., Schultz, K.S., Baltes, B. and Stolz, H.E. (2004), "Men's and women's eldercare-based work -family conflict: antecedents and work-related outcomes", Fathering, Vol. 2 No. 3, pp. 305-330.

Berry, P. and Franks, T.J. (2010), "Women in the world of corporate business: looking at the glass ceiling", Contemporary Issues in Education Research, Vol. 3 No. 2, p. 1.

Boyar, S.L., Maertz, C.P. and Pearson, A.W. (2005), "The effects of work-family conflict and family-work conflict on non-attendance behaviors", Journal of Business Research, Vol. 58 No. 7, pp. 919-925.

Brammer, S. and Millington, A. (2006), "Firm size, organizational visibility and corporate philanthropy: an empirical analysis", Business Ethics, Vol. 15 No. 1, pp. 6-18.

Bruck, C.S., Allen, T.D. and Spector, P.E. (2002), "The relation between work-family conflict and job satisfaction: a finer-grained analysis", Journal of Vocational Behavior, Vol. 60 No. 3, pp. 336-353.

Calvo, J.C.A. and Martínez, E.N. (2004), "Efectos tamaño y sector sobre la rentabilidad, endeudamiento y coste de la deuda de las empresas familiares riojanas", Cuadernos de Gestión, Vol. 4 No. 1, pp. 35-54.

Cánovas, A., Aragón, J. and Rocha, F. (2005), "Reconciliation of work and family policies in the autonomous communities", Cuadernos de Relaciones Laborales, Vol. 23 No. 1, pp. 73-93. 
EJMBE

27,3
Carrasquer, P. and Martín, A. (2005), "La política de conciliación de la vida laboral y familiar en la negociación colectiva. Un aspecto de la estrategia europea de empleo", Cuadernos de Relaciones Laborales, Vol. 23 No. 1, pp. 131-150.

Cegarra-Leiva, D., Sánchez-Vidal, M.E. and Cegarra-Navarro, J. (2012a), "Work life balance and the retention of managers in Spanish SMEs", The International Journal of Human Resource Management, Vol. 23 No. 1, pp. 91-108.

Cegarra-Leiva, D., Sánchez-Vidal, M.E. and Cegarra-Navarro, J.G. (2012b), "Understanding the link between work life balance practices and organisational outcomes in SMEs: the mediating effect of a supportive culture", Personnel Review, Vol. 41 No. 3, pp. 359-379.

Coller, X., Cambra-Fierro, J., Gulatieri, T. and Melero-Polo, I. (2014), "An opportunity to improve working conditions through CSR", in Preuss, L., Gold, M. and Rees, C. (Eds), Corporate Social Responsibility and Trade Unions: Perspectives Across Europe, Routledge, New York, NY, pp. 151-168.

Davis, K. (1973), "The case for and against business assumption of social responsibilities", Academy of Management Journal, Vol. 16 No. 2, pp. 312-322.

De Luis-Carnicer, M.P., Martínez-Sánchez, A., Pérez-Pérez, M. and Vela Jiménez, M.J. (2004), "Work-family conflict in a southern European country: the influence of job-related and non-related factors", Journal of Managerial Psychology, Vol. 19 No. 5, pp. 466-489.

Dex, S. and Scheibl, F. (2000), "Business performance and family-friendly policies", Journal of General Management, Vol. 25 No. 4, pp. 22-37.

Dezsö, C.L. and Ross, D.G. (2012), "Does female representation in top management improve firm performance? A panel data investigation”, Strategic Management Journal, Vol. 33 No. 9, pp. 1072-1089.

Eckel, C., De Oliveira, A. and Grossman, P.J. (2008), "Gender and negotiation in the small: are women (perceived to be) more cooperative than men?", Negotiation Journal, Vol. 24 No. 4, pp. 429-445.

European Commission (2001), "Promoting a European framework for corporate social responsibility - Green Paper", Office for Official Publications of the European Communities, Luxembourg.

European Foundation for the Improvement of Living and Working Conditions (2010), Changes Over Time - First Findings from the Fifth European Working Conditions Survey, European Foundation for the Improvement of Living and Working Conditions, Dublin.

Fernández, J.L. and Luna, L. (2007), "The creation of value through corporate reputation", Journal of Business Ethics, Vol. 76 No. 3, pp. 335-346.

Forma, P. (2009), "Work, family and intentions to withdraw from the workplace”, International Journal of Social Welfare, Vol. 18 No. 2, pp. 183-192.

Gil-Estallo, M.D.L.A., Giner-de-la-Fuente, F. and Gríful-Miquela, C. (2009), "Benchmarking corporate social responsibility within Spanish companies", International Advances in Economic Research, Vol. 15 No. 2, pp. 207-225.

Glass, J.L. and Estes, S.B. (1997), "The family responsive workplace”, Annual Review of Sociology, Vol. 23 No. 1, pp. 289-313.

Glass, J.L. and Finley, A. (2002), "Coverage and effectiveness of family-responsive workplace policies", Human Resource Management Review, Vol. 12 No. 3, pp. 313-337.

Grau-Grau, M. (2013), "Clouds over Spain: work and family in the age of austerity”, International Journal of Sociology and Social Policy, Vol. 33 Nos 9/10, pp. 579-593.

Greenhaus, J.H. and Parasuraman, S. (1997), "The integration or work and family life: barriers and solutions", in Parasuraman, S. and Greenhaus, J.H. (Eds), Integrating Work and Family: Challenges and Choices for a Changing World, Quorum, Westport, CT, pp. 232-240.

Griffin, J.J. and Mahon, J.F. (1997), "The corporate social performance and corporate financial performance debate: twenty-five years of incomparable research", Business \& Society, Vol. 36 No. 1 , pp. 5-31. 
Grzywacz, J.G. and Marks, N.F. (2000), "Family, work, work-family spillover, and problem drinking during midlife", Journal of Marriage and Family, Vol. 62 No. 2, pp. 336-348.

Hall, D.T. and Parker, V.A. (1993), "The role of workplace flexibility in managing diversity", Organizational Dynamics, Vol. 22 No. 1, pp. 5-18.

Havlovic, S.J. (1991), "Quality of work life and human resource outcomes", Industrial Relations, Vol. 30 No. 3, pp. 469-479.

Hughes, J. and Bozionelos, N. (2007), "Work-life balance as source of job dissatisfaction and withdrawal attitudes: an exploratory study on the views of male workers", Personnel Review, Vol. 36 No. 1, pp. 145-154.

Huselid, M. (2003), "Research linking HRM systems with firm performance”, available at: http://markhuselid. com/pdfs/articles/2003_SHRM_Empirical_Studies_Summary_95-03.pdf (accessed July 2017).

Husted, B.W. and Allen, D.B. (2007), "Strategic corporate social responsibility and value creation among large firms: lessons from the Spanish experience", Long Range Planning, Vol. 40 No. 6, pp. 594-610.

Hyman, J., Baldry, C., Scholarios, D. and Bunzel, D. (2003), "Work-life imbalance in call centres and software development”, British Journal of Industrial Relations, Vol. 41 No. 2, pp. 215-239.

Idrovo Carlier, S., Leon Llorente, C. and Grau Grau, M. (2012), “Comparing work-life balance in Spanish and Latin-American countries", European Journal of Training and Development, Vol. 36 Nos 2/3, pp. 286-307.

International Labor Organization (2016), Las Mujeres en el Trabajo, Tendencias 2016, Organización Internacional del trabajo (OIT), Ginebra.

Kar, S. and Misra, K.C. (2013), "Nexus between work life balance practices and employee retention-the mediating effect of a supportive culture", Asian Social Science, Vol. 9 No. 11, pp. 63-69.

Konrad, A.M. and Mangel, R. (2000), "The impact of work-life programs on firm productivity”, Strategic Management Journal, Vol. 21 No. 12, pp. 1225-1237.

Kossek, E., Lewis, S. and Hammer, L. (2010), "Work-life initiatives and organizational change: overcoming mixed messages to move from the margin to the mainstream", Human Relations, Vol. 63 No. 1, pp. 3-19.

Kossek, E.E. and Ozeki, C. (1998), "Work-family conflict, policies, and the job-life satisfaction relationship: a review and directions for organizational behavior-human resources research", Journal of Applied Psychology, Vol. 83 No. 2, pp. 139-149.

Lambert, E.G., Baker, D.S., Cluse-Tolar, T., Jennings, M. and Pasupuleti, S. (2006), "The impact of work-family conflict on social work and human service worker job satisfaction and organizational commitment”, Administration in Social Work, Vol. 30 No. 3, pp. 55-74.

Lambert, S.J. (2000), "Added benefits: the link between work-life benefits and organizational citizenship behavior", Academy of Management Journal, Vol. 43 No. 5, pp. 801-815.

Lobel, S.A. (1999), "Impacts of diversity and work-life initiatives in organizations", in Powell, G.N. (Ed.), Handbook of Gender and Work, Sage publications, CA, pp. 453-476.

Lu, L., Kao, S., Chang, T., Wu, H. and Cooper, C.L. (2008), "Work/family demands, work flexibility, work/family conflict, and their consequences at work: a national probability sample in Taiwan", International Journal of Stress Management, Vol. 15 No. 1, pp. 1-21.

Macinnes, J. (2005), "Diez mitos sobre la conciliación de la vida laboral y familiar", Cuadernos de Relaciones Laborales, Vol. 23 No. 1, pp. 35-71.

Mahoney, L. and Roberts, R.W. (2007), "Corporate social performance, financial performance and institutional ownership in Canadian firms", Accounting Forum, Vol. 31 No. 3, pp. 233-253.

Mañas, E. and Garrido, R. (2008), "La compatibilidad entre trabajo y vida personal: un nuevo reto para las empresas españolas”, Economía Industrial, Vol. 367 No. 1, pp. 167-184.

Martínez, J.B., Fernández, M.L. and Fernández, P.M.R. (2016), "Corporate social responsibility: evolution through institutional and stakeholder perspectives", European Journal of Management and Business Economics, Vol. 25 No. 1, pp. 8-14. 
EJMBE

27,3

Matus, M., Calderón, F.J. and Gómez, A. (2007), "La incorporación de medidas de conciliación de la vida familiar y laboral en los convenios colectivos: el caso andaluz. Temas Laborales", Revista Andaluza de Trabajo y Bienestar Social, Vol. 1 No. 88, pp. 27-53.

Maxfield, S. (2005), "Modifying best practices in women's advancement for the Latin American context", Women in Management Review, Vol. 20 No. 4, pp. 249-261.

Melé, D., Debeljuh, P. and Arruda, M.C. (2006), "Corporate ethical policies in large corporations in Argentina, Brazil and Spain”, Journal of Business Ethics, Vol. 63 No. 1, pp. 21-38.

Meyer, C.S., Mukerjee, S. and Sestero, A. (2001), "Work-family benefits: which ones maximize profits?", Journal of Managerial Issues, Vol. 13 No. 1, pp. 28-44.

Miller, T. and Triana, M.D.C. (2009), "Demographic diversity in the boardroom: mediators of the board diversity-firm performance relationship", Journal of Management Studies, Vol. 46 No. 5, pp. 755-786.

Ngo, H., Foley, S. and Loi, R. (2009), "Family friendly work practices, organizational climate, and firm performance: a study of multinational corporations in Hong Kong", Journal of Organizational Behavior, Vol. 30 No. 5, pp. 665-680.

Odriozola, M.D. and Baraibar-Diez, E. (2017), "Is corporate reputation associated with quality of CSR reporting? Evidence from Spain", Corporate Social Responsibility and Environmental Management, Vol. 24 No. 2, pp. 121-132.

Osterman, P. (1995), "Work/family programs and the employment relationship", Administrative Science Quarterly, Vol. 40 No. 4, pp. 681-700.

Pasamar, S. and Valle, R. (2011), "Work-life balance in Spanish companies: myth or reality?", Universia Business Review, Vol. 1 No. 29, pp. 14-31.

Poelmans, S. (2001), "A qualitative study of work-family conflict in managerial couples", Research Paper No. 444, IESE, Barcelona.

Poelmans, S.A. (2005), Work and Family: An International Research Perspective, Psychology Press, Erlbaum, Mahwah, NJ.

Prósper, V.F. and Reche, A.G. (2011), "Análisis de la evolución de las políticas y prácticas de responsabilidad social en las empresas del IBEX 35 en el período 2005-2008”, in Antuñano, I., Jordán, J.M. and Carpi, J.A.T. (Eds), Crisis y transformación. Una perspectiva de política económica: Ensayos en homenaje al profesor Emèrit Bono, Universitat de València, Valencia, Vol. 117-134.

Roberts, R.W. (1992), "Determinants of corporate social responsibility disclosure: an application of stakeholder theory”, Accounting Organisations and Society, Vol. 17 No. 6, pp. 595-612.

Rogelberg, S.G. and Rumery, S.M. (1996), "Gender diversity, team decision quality, time on task, and interpersonal cohesion”, Small Group Research, Vol. 27 No. 1, pp. 79-90.

Rothbard, R., Philips, K. and DUMAS, T. (2005), "Multiple roles: work-family policies and individual's desires for segmentation”, Organizational Science, Vol. 16 No. 3, pp. 243-258.

Scandura, T.A. and Lankau, M.J. (1997), "Relationships of gender, family responsibility and flexible work hours to organizational commitment and job satisfaction”, Journal of Organizational Behavior, Vol. 18 No. 4, pp. 377-391.

Schieman, S., Mcbrier, D.B. and Gundy, K.V. (2003), "Home-to-work conflict, work qualities, and emotional distress", Sociological Forum, Vol. 18 No. 1, pp. 137-164.

Seierstad, C. and Kirton, G. (2015), "Having it all? Women in high commitment careers and work-life balance in Norway”, Gender, Work and Organization, Vol. 22 No. 4, pp. 390-404.

Siegel, P.A., Post, C., Brockner, J., Fishman, A. and Garden, C. (2005), "The moderating influence of procedural fairness on the relationship between work-life conflict and organizational commitment", Journal of Applied Psychology, Vol. 90 No. 1, pp. 13-24.

Straub, C. (2007), "A comparative analysis of the use of work-life balance practices in Europe: do practices enhance females' career advancement?", Women in Management Review, Vol. 22 No. 4, pp. 289-304. 
Valle, R., Martín, F. and Romero, P.M. (2001), "Trends and emerging values in human resource management: the Spanish scene”, International Journal of Manpower, Vol. 22 No. 3, pp. 244-251.

Wang, P., Lawler, J.J., Walumbwa, F.O. and Shi, K. (2004), "Work-family conflict and job withdrawal intentions: the moderating effect of cultural differences", International Journal of Stress Management, Vol. 11 No. 4, pp. 392-412.

Williams, R.J. (2003), "Women on corporate boards of directors and their influence on corporate philanthropy”, Journal of Business Ethics, Vol. 42 No. 1, pp. 1-10.

\section{Further reading}

Cappelli, P. (2000), “A market-driven approach to retaining talent”, Harvard Business Review, Vol. 78 No. 1, pp. 103-111.

[Dataset] Eurostat Statistics Explained (2017), "Number of persons by sex, age groups, household composition and working status", Labour market and Labour force survey (LFS) statistics, available at: http://ec.europa.eu/eurostat/statistics-explained/index.php/Labour_market_and_ Labour_force_survey_(LFS)_statistics (accessed 18 July 2017).

Felmlee, D.H. (1995), “Causes and consequences of women's employment discontinuity, 1967-1973", Work and Occupations, Vol. 22 No. 2, pp. 167-187.

Observatory for CSR - UGT (2008/2013), "Cultures, policies and practices of corporate social responsibility of Ibex35 companies", Reports 2008-2013, available at: www.observatorio-rse.org.es (accessed 5 May 2015).

Veiga, J.F., Baldridge, D.C. and Eddleston, K.A. (2004), "Toward understanding employee reluctance to participate in family-friendly programs", Human Resource Management Review, Vol. 14 No. 3, pp. 337-351.

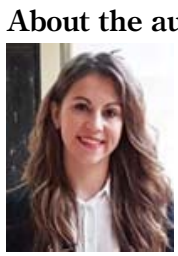

María Dolores Odriozola is Lecturer of Business Administration and Researcher of the "Economic Management for the Primary Sector Sustainability" research group (IDES) at University of Cantabria. She has completed her MBA from the University of Cantabria, and has $\mathrm{PhD}$ in Business Administration from the University of Cantabria in 2015. Her primary research areas include social responsibility in the field of human resources, labour reputation and corporate reputation. María Dolores Odriozola is the corresponding author and can be contacted at: odriozolamd@unican.es

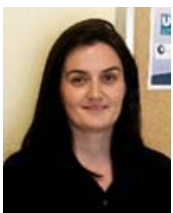

Elisa Baraibar-Diez is Lecturer of Business Administration and Researcher of the "Economic Management for the Primary Sector Sustainability" research group (IDES) at University of Cantabria. She has completed her MBA from the University of Cantabria, and has $\mathrm{PhD}$ in Business Administration from the University of Cantabria in 2013. Her primary research areas include transparency, corporate social responsibility, corporate reputation and corporate governance.

For instructions on how to order reprints of this article, please visit our website: 